\title{
Entrevista com Pedagogo responsável pelo conteúdo dos exercícios on-line do site www.kademi.com.br
}

\section{Entrevistado:}

Ricardo de MACEDO

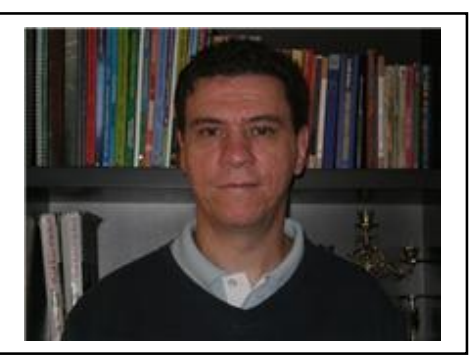

Professor, Formado pela Universidade Guarulhos (2005) com graduação em Letras, Português e Literatura e Estudos Comparados de Literatura e Língua Portuguesa (nível mestrado) pela USP - Universidade de São Paulo. Experiência de mais de 10 anos como professor na rede particular de ensino, atuando, principalmente, nas seguintes disciplinas: Língua Portuguesa, Literatura, História e Crítica literária. Professor de literatura em curso pré-vestibular do Colégio Integrado.

Contato: rmacedo.usp@gmail.com

\section{Entrevistadora:}

Maria da Glória de AMARAL

Psicóloga formada pelo IPUSP e aluna do curso de Pedagogia da FEUSP.

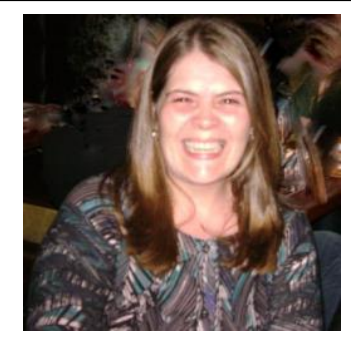

1) Qual a diferença entre alfabetização e letramento em sua opinião? 
$\mathrm{Na}$ alfabetização o educando domina a escrita e a leitura. Compreende a fundição dos fonemas e a formação das palavras etc. Já o ser letrado consegue ir mais além dos caracteres e fonemas. Ele possui em si a 
capacidade de compreender os signos linguísticos e os significados dos mesmos, sabe usar a "chave de leitura" para assim esmiuçar, debater, ir a fundo num determinado texto: verbal, visual e verbo-visual.

2) Como você define o conteúdo dos exercícios de língua portuguesa, do site kademi, para as crianças entre seis e dez anos?

Conteúdos que contribuem na formação do aluno: tanto na escrita quanto na leitura, portanto o Kademi busca por meio dos seus conteúdos fazer com que seus navegantes, ou seja, os alunos que usam o site desenvolvam as várias inteligências múltiplas inerentes e latentes em todo ser humano.

3) Pelo nível de acesso e acerto dos exercícios realizados no site, pelas crianças, qual o conteúdo com o qual elas mais se identificam ou demonstram mais facilidade?

Os conteúdos que misturam os textos: verbal, visual e verbo visual e, além disso, no Kademi existe um diferencial. Trata-se da abordagem desses conteúdos por meio de games (daí fica mais interessante para a criança).

4) Você considera que esses exercícios de língua portuguesa do site contribuem com o processo de alfabetização e letramento das crianças?

Eu diria que além de contribuir ele também incentiva a criança em buscar sempre mais. É uma maneira ultramoderna e revolucionária de alfabetização e por consequiência o letramento.

5) Como você avalia a influência do aprendizado de língua portuguesa nas demais disciplinas?

A língua portuguesa é a base para todas as outras disciplinas, pois se um aluno não sabe "ler" uma questão de biologia ou de geografia ele não conseguirá resolvê-las. A língua portuguesa é o caminho onde o aluno despertará todas as suas inteligências.

6) Vocês tem registro de utilização do Kademi por crianças que residem em outros países?

O Kademi ainda não atravessou nossas fronteiras. Porém sabemos que a Língua Portuguesa já é unificada e assim não nos impede de ir além, isto é, 
aos outros países de língua portuguesa. Seria interessante pensar em um aluno da África usando o Kademi.

O universo dos jogos eletrônicos mexe com o imaginário da criança e ajuda a desenvolver habilidades de aprendizagem interessantes, pois a principal característica do ato de jogar é a capacidade de aprender através da vivência do jogo.

Para "passar de fase" a criança tem que acertar e vai "aprendendo" a acertar na medida em que erra e tem que retroceder para poder avançar novamente; o poder de concentração é outro estímulo gerado pelos jogos, dentre tantos outros.

Vale lembrar que quando se fala de jogos há uma questão cultural a ser levantada: informações da cultura de onde vem esse jogo, portanto, os jogos desenvolvidos em português trazem contidos em si todas as questões inerentes a cultura daquela língua.

Quando a criança joga, ela vivencia as emoções contidas naquele jogo, na fase de alfabetização isso se torna um fator importante devido a interação da criança com as palavras, com os significados e as sensações que elas produzem.

A questão dos jogos, ou da tecnologia como um todo, é um desafio aos professores: fazer com que essas ferramentas, de fato, auxiliem o ensino e a produção de conhecimento em sala de aula não é tarefa fácil.

Por essa razão, o Kademi ampliou seu espectro de atuação nos últimos dois anos: no início, o site destinava-se apenas aos alunos, para que os mesmos jogassem em casa e servia como um complemento aos deveres de casa, hoje o site também é destinado as escolas e aos professores, que o utilizam como ferramenta didática também.

Essa etapa se constituiu em um desafio também, pois, incorporar os jogos as ferramentas didáticas requer treino e capacitação dos professores e a maioria das escolas, muitas vezes, não dispõem de todos os recursos tecnológicos necessários. 
Por fim, existe ainda um grande preconceito de pais, professores e diretores em relação a esse tipo de recurso.

Os jogos eletrônicos, em geral, especialmente os videogames e jogos na internet, muitas vezes são vistos pelos pais como um grande pesadelo.

Não importa se é dia ou noite, quando estão jogando as crianças, em geral, nem percebem o tempo passar, ficam imersos em um mundo tridimensional onde tudo é possível e, muitas vezes, mantém-se isolados dos demais membros da família jogando, jogando e jogando, como entender, então, que os jogos possam auxiliar nos estudos?

Esta experiência tem demonstrado que transformar o conteúdo didático em jogos e exercícios pode transformar essa atividade em algo muito prazeroso para a criança, auxiliar a escola e integrar os pais nessa atividade, pois muitos jogos e exercícios estimulam a participação de um outro "jogador".

\section{Como citar este texto:}

AMARAL, M. G. Entrevista - Ricardo de Macedo. Responsável pelo conteúdo dos exercícios on-line do site www.kademi.com.br. Revista Acolhendo a alfabetização nos países de língua portuguesa, Brasil, São Paulo, volume 1, no. 13, pp. 136 - 139, Set. 2012. Disponível em: <http://www.acoalfaplp.net>. 